\title{
Review on Agricultural Extension Impacts on Food Crop Diversity and the Livelihood of Farmers in Ethiopia
}

\author{
Alemayehu Keba ${ }^{1 *}$ and Musba Kedir ${ }^{2}$ \\ ${ }^{1}$ Ethiopian Institute of Agricultural Research, P.O.Box 2003, Addis Ababa, Ethiopia \\ ${ }^{2}$ Ethiopian Institute of Agricultural Research, P.O.Box 2003, Addis Ababa, Ethiopia
}

*Corresponding author: Alemayehu Keba, Ethiopian Institute of Agricultural Research, P.O.Box 2003, Addis Ababa, Ethiopia.
Received Date: September 04, 2020

Published Date: September 21, 2020

\begin{abstract}
Agricultural extension could be one tool in attaining the sustainable development goal related to the reduction of extreme poverty and hunger in developing countries like Ethiopia. This review aimed on agricultural extension impacts on food crop diversity and the livelihood of farmers in Ethiopia. According to this review results, agricultural extension impacts on food crop diversity are significantly affected positively and negatively with or without establishing annual joint planning, monitoring, learning, and evaluation, experience sharing through workshops, trainings and joint field visits in a cost-effective manner respectively. In addition, putting in place effective regulatory system and strategic framework for NGO's extension services through developing extension governance structure are importantly affect agricultural extension towards of food crop diversity and also the possible explanation is that access to extension services is associated with the spread and adoption of new technologies through the provision of technical advice, credit availability, input supplies and even to the provision of market information and building the capacity of farmers, which might be directly re Cooperatives can provide specialized extension services by employing extension agents and/or contracting extension service providers to maximize their expected outputs to their members both in terms of improving the quantity and quality of their produce/ products. According to this review results, agricultural extension impacts the livelihood of farmers are affected by series of agricultural policies and strategies to nurture service provision and promote rural development, practical skills development and learning knowledge and trainings about crop production, natural resources management and animal production at different rates. Therefore, it is important for the government to focus on the awareness of the small holder farmers the way of enhancing the crop diversification and changing their own livelihood by using agricultural extension policies and strategy that is released or prepared by government or non-government organization.
\end{abstract}

Keywords: Agricultural extension impacts, crop diversity, livelihood, Ethiopia

Abbreviations: ATVET - Agricultural Technical and Vocational Education Training; Das - Development Agents; FTCs - Farmers Training Centers; GDP - Gross Domestic Product; NEIP - National Extension Intervention Program; NGO's - Non-governmental organizations; PADETES - Participatory Demonstration Training and Extension System; SSA - Sub-Saharan Africa

\section{Introduction}

\section{Background and justification of the review}

Increasing agricultural productivity is a key challenge in SubSaharan Africa (SSA), where $62 \%$ of the population (excluding
South Africa) depends on agriculture for their livelihoods [1]. Since 1960s, agricultural production in SSA has failed to keep up pace with population growth [2]. Improving the productivity, profitability, and sustainability of smallholders farming is therefore 
the main pathway to get out of poverty [3]. It is widely argued that, achieving agricultural productivity growth will not be possible without developing and disseminating improved agricultural technologies that can increase productivity to smallholder agriculture [4]. Agriculture is the foundation of Ethiopian economy. Being the dominant sector, agriculture contributes about $46.3 \%$ of the total gross domestic product (GDP), $60 \%$ of exports, and $80 \%$ of total employment.

- Agricultural production is dominated by smallholder households which produce more than $90 \%$ of agricultural output.

- Smallholders drive their income either in cash or through own consumption from agricultural production.

- According to the national accounts, the agricultural sector consists of crop, livestock, fishery and forestry sub-sectors. Crop production is the dominant sub-sector within agriculture [5].

Ethiopian agriculture is rainfall dependent and subsistence oriented. Most of the outputs come from small-scale farmers who undertake traditional farming practices using traditional farming tools. There is a significant variation in terms of landform, soil types, climate, farming practices, etc., which provides the country with different types of livestock and a variety of food crops, vegetables and fruits. Agricultural extension could be one tool in attaining the millennium development goal related to the reduction of extreme poverty and hunger in developing countries like Ethiopia. Though extension was practiced for many years in Ethiopia, it is recently that small-scale farmers have got attention [6].

There has been growing awareness that sustained increases in poverty reduction in Ethiopia are more likely to be achieved through improvement in the agriculture sector. Hence, several extension approaches have been followed in Ethiopia since 1950's and various programs were implemented to provide farmers with relevant agricultural information and appropriate technologies that could improve productivity and household income. Since 1995 the extension program known as Participatory Demonstration Training and Extension System (PADETES) which falls under the National Extension Intervention Program (NEIP) has been implemented focusing on supply-driven package approach which consists of enhanced supply and promotion of improved seeds, fertilizers, on farm demonstrations of improved farm practices and technologies and close follow up of farmers' plots [4,7-9]. However, in spite of implementing the agricultural extension program Ethiopia remains one of the poorest countries in the world [10], vulnerable to recurrent food shortfalls, national food insecurity [11] and widespread rural poverty [12].

Like in many other SSA countries, agriculture is the most important sector for sustaining growth and reducing poverty in Ethiopia. It accounts for $85 \%$ of employment, 50\% of exports, and $43 \%$ of gross domestic product (GDP) [13]. However, lack of adequate farm management practices, low level of modern inputs usage, the depletion of soil organic matter and soil erosion, highly rain fed dependent agriculture system are major obstacles to sustain the agricultural production in the country [14].

Extension is provided primarily by the public sector, operating in a decentralized manner through which extension is implemented at the woreda (district) and kebele (Peasant association) level. Almost in its two decade's life, PADETES program has increased the number of public Development Agents (DAs) dramatically from 2,500 to 47,500 during the period of 1995 to 2008 through the provision of a three-year diploma program at Agricultural Technical and Vocational Education Training (ATVET) colleges. This rapid expansion has been accompanied by the establishment of Farmers Training Centers (FTCs) to become the focal point of extension support with a range of technical skills and provide abroad range of demand-responsive extension and short-term training services in every kebele in the country. Each FTC is to be staffed by three DAs (one each in the areas of crops, livestock, and natural resource management) [12].

There have been few studies conducted on agricultural extension impacts on food crop diversity and the livelihood of farmers in Ethiopia. In spite of the fact that the Ethiopian government gave special attention to the agricultural sector and tried to establish and support agricultural research institutes, research places in the country are too few to cover the whole country. Improved seeds are basically tried in few research places and at farmers' fields near the places but disseminated to a large area. However, it is very important to the knowledge of the authors, collecting very limited analysis of agricultural extension impacts on food crop diversity and the livelihood of farmers and also the existing domain of research and development endeavors so far seem to be unable to provide adequate empirical explanation so identified their gap is very important.

\section{Objective}

Review on Agricultural extension impacts on food crop diversity and the livelihood of farmers in Ethiopia

\section{Literature Review}

\section{Definitions and concepts}

The meaning of the term 'extension 'has changed over time [15] and is moving away from the dominant emphasis on technology transfer (reflected, for example, in the training and visit approach) towards a much broader concept that includes developing the skills and management capacities of farming families (through the farmer field school approach, for example) and the learning capacity of both farmers and extension organizations. Extension has been recently defined as "systems that facilitate the access of 
farmers, their organizations and other market actors to knowledge, information and technologies; facilitate their interaction with partners in research, education, agribusiness, and other relevant institutions; and assist them to develop their own technical, organizational and management skills and practices" [16].

Pluralistic agricultural extension and advisory services comprise "all the different activities that provide the information, [goods,] and services needed and demanded by farmers and other actors in agricultural settings to assist them in developing their own technical, organizational, and management skills and practices so as to improve their livelihoods and well-being" [16].

Agricultural extension' describes the services that provide rural people with the access to knowledge and information they need to increase productivity and sustainability of their production systems and improve their quality of life and livelihoods. It includes, but is not limited to, the transfer of knowledge generated by agricultural research. It has helped countries move towards meeting food needs, conserving natural resources and developing human and social capital. Different players see extension as having different objectives, ranging from overtly political rural campaigning, through commercial promotion of specific commodity production, to the social aims of promoting and implementing poverty reducing programs. Not surprisingly, this lack of clear purpose, along with other factors (see below), has been seen as contributing to very variable results in terms of adoption of recommended practices, increased productivity or impact on rural poverty. Many are questioning whether national extension services in their traditional form are appropriate and sustainable given the high costs of maintaining these services and the general decline in funding for them [17].

Some would give greater and more explicit emphasis to the importance of a multidirectional flow of information that potentially influences research programs and agendas (for example, from farmers to extension agencies and researchers), as opposed to the unidirectional flow embodied in traditional research and extension systems. This kind of process may be better describing as 'innovation' rather than 'extension'. Experience suggests that actors in agricultural innovation systems must be in closer contact with their clients if systems are to be demand-led and that poor farmers must be better represented and more actively involved if their needs are to be me [17].

\section{Review on agricultural extension impact on food crop diversity in Ethiopia}

The current increasing demands from farmers on agricultural extension services requires the alignment between public and NGO's. This alignment can be realized through establishing annual joint planning, monitoring, learning, and evaluation, experience sharing through workshops, trainings and joint field visits in a costeffective manner. In addition, putting in place effective regulatory system and strategic framework for NGO's extension services through developing extension governance structure are critically important. Installation of effective regulatory system and strategic framework for NGO's extension services through developing extension governance structure is critically important [18].

According to [19] studies result Extension service affected crop diversification positively and significantly. The possible explanation is that access to extension services is associated with the spread and adoption of new technologies through the provision of technical advice, credit availability, input supplies and even to the provision of market information and building the capacity of farmers, which might be directly relevant to cereal diversification. Likewise, other studies found that extension contacts increased crop diversification in SNNPR of Ethiopia [20].

A study presented by [21] clearly indicated the importance of cooperatives in agricultural extension service provision. Cooperatives can provide specialized extension services by employing extension agents and/or contracting extension service providers to maximize their expected outputs to their members both in terms of improving the quantity and quality of their produce/products. To achieve this, farmer's cooperatives need to get necessary capacity building support in all aspects including, governance, leadership, and value chain development and engaged to provide need based and market driven extension services to farmers.

Throughout the past rural development programmes, Ethiopia has put major stress on the role of information and training for farmers. A major initiative in the first poverty strategy was the development of the widespread extension programme PADETES, including advanced training programmes for extension agents. Through this system, the government also delivered off-theshelf packages of fertilizer, improved seed and credit, as well as information on input use and better agricultural practices, to the vast majority of smallholders in rural areas. Ethiopia has the highest extension-to-farmer rate in Africa [22].

\section{Review on agricultural extension impacts on the livelihood of farmers in Ethiopia}

According to the findings of [23] the Ethiopian state has invested considerable resources in maintaining a strong agricultural extension system. Over the years, the state has developed and issued a series of agricultural policies and strategies to nurture service provision and promote rural development. However, the strategies are typically not well communicated to the actors and end users. The implementation of the participatory extension system is also inconsistent, showing limited impact and sustainability across 
study sites. This study indicates that along with the public, involving the private and non-governmental organizations extension services may allow other actors to be involved in the extension services and help address the prevailing gaps of inadequate capacity and skills, shortage of inputs such as improved seeds, and price escalation. Understanding strengths, limitations and reform options of the current system through the lens of Evolutionary Governance Theory, can also enable top actors/planners to formulate better policies and strategies. Introducing pro-poor strategies is vital to involve the disadvantaged groups of the society.

To understand the activities of the FTC the approach of these institutions was also assessed. What can be deducted from these results is that farmers are interested in on hand practical skills development and are mostly interested in learning knowledge that is proved to work. Therefore, it is important to focus on the approaches that combine on hand skills accumulation and are beneficial to their livelihoods" activities [24].

FTC users were satisfied by the trainings about crop production, natural resources management and animal production at different rates. The results also indicated that the majority of the users recognized to have benefited from FTCs trainings in terms of developing the culture of saving, access to market and improved knowledge on agriculture and environment. Nevertheless, most of the FTC-users evaluated the training received as irrelevant to their needs. Qualitative analysis revealed the most critical challenges of FTC were the lack of necessary resources and equipment. The study concludes that the contribution of FTCs practices on farmers livelihoods in the study area has both negative for landless youth and positive in improving farmers livelihood $[25,26]$.

\section{Conclusion}

Agricultural extension could be one tool in attaining the sustainable development goal related to the reduction of extreme poverty and hunger in developing countries like Ethiopia. Though extension was experienced for many years in Ethiopia, it is recently that small-scale farmers have got attention. Agricultural extension impacts on food crop diversity are significantly affected positively and negatively with or without establishing annual joint planning, monitoring, learning, and evaluation, experience sharing through workshops, trainings and joint field visits in a cost-effective manner respectively. Agricultural extension impacts the livelihood of farmers are affected by series of agricultural policies and strategies to nurture service provision and promote rural development, practical skills development and learning knowledge and trainings about crop production, natural resources management and animal production at different rates.

\section{Recommendation}

It is important for the government to focus on the awareness of the small holder farmers the way of enhancing the crop diversification and changing their own livelihood by using agricultural extension policies and strategy that is released or prepared by government or non-government organization.

\section{Acknowledgement}

None.

\section{Conflict of Interest}

No Conflict of Interest.

\section{References}

1. Staatz J, Dembele N (2007) Agriculture for development in sub-saharan Africa. Background paper for the World Development Report 2008.

2. Benin S (2006) Policies and programs affecting land management practices, input use, and productivity in the highlands of Amhara Region, Ethiopia. In J Pender, F Place, \& S Ehui (Eds.), Strategies for Sustainable Land Management in the East African Highlands. Washington, DC: IFPRI.

3. World Development Report (WDR) (2008) Agriculture for development. The World Bank, Washington, DC Yilmaz S, \& Venugopal V (2008). Local government discretion and accountability in Ethiopia. International Studies Program Working Paper 08-38, Atlanta: Georgia State University.

4. Asfaw S, Shiferaw B, Simtowe F, Lipper L (2012) Impact of modern agricultural technologies on smallholder welfare: Evidence from Tanzania and Ethiopia. Food policy 37: 283-295.

5. Solomon Yokamo (2020) Historical Perspectives of Agricultural Extension and Research-Extension-Farmers Linkage in Ethiopia. Acta Scientific Agriculture 4(5): 28-33.

6. Biratu GK (2008) Agricultural extension and its impact on food crop diversity and the livelihood of farmers in Guduru, Eastern Wollega, Ethiopia.

7. Gebremedhin B, Jalata M, Hoekstra D (2009) Smallholders, Institutional Services, and Commercial Transformation in Ethiopia. J Agr Econ 40: 773-787.

8. Kassa B, Abebaw D (2004) Challenges Facing Agricultural Extension Agents: A Case Study from South-Western Ethiopia. Afr Dev Rev 16(1): 139-168.

9. Kassa H (2008) Agricultural Extension in Ethiopia: Historical Evolution, Relevant Policies and Challenges. In: "Digest of Ethiopia's National Policies, Strategies and Programs", (Ed.): Assefa T. Eclipse Printers, Addis Ababa.

10. USAID (2013) Empowering Women through Agricultural Development in Ethiopia.

11. Abate T, Shiferaw B, Gebeyehu S, Amsalu B, Negash K, et al. (2011) Systems and Partnership Approach to Agricultural Research for Development: Lessons from Ethiopia. Outlook Agric 40(3): 213-220.

12. Spielman DJ, Davis K, Negash M, Ayele G (2011) Rural Innovation Systems and Networks: Findings from a Study of Ethiopian Smallholders. Agr Hum Value 28: 195-212.

13. FAO (Food and Agriculture Organization of the United Nations) (2010) Ethiopia country brief.

14. Kassie M, Zikhali P, Manjur K, Edward E (2009) Adoption of sustainable agriculture practices: Evidence from a semi-arid region of Ethiopia. Natural Resources Forum 39: 189-98

15. Swanson BE (2008) Global Review of Good Agricultural Extension and Advisory Services Practices. Rome: FAO.

16. Christoplos I (2010) Mobilising the Potential of Rural and Agricultural Extension. Neuchatel Group.

17. Natural Resources Institute University of Greenwich Medway Campus (2014) Agricultural Extension, Advisory Services and Innovation. 
18. ATA (2017) Ethiopia's Agricultural Extension Strategy. Addis Ababa.

19. Mussema R, Kassa B, Alemu D, Shahidur R (2015) Determinants of crop diversification in Ethiopia: Evidence from Oromia region. Ethiopian Journal of Agricultural Sciences 25(2): 65-76.

20. Rehima, Mussema, Belay Kassa, Dawit Alemu, S Rashid (2013) Factors affecting farmers' crops diversification: Evidence from SNNPR, Ethiopia. Int J of Agric Sci 3(6): 558-565.

21. Quinones, Marco A (2010) Agriculture-Led Development in Ethiopia. Submitted to Federal Democratic Republic of Ethiopia, Ministry of Agriculture. Addis Ababa, Ethiopia.

22. Ragasa C, Berhane G, Tadesse F, AS Taffesse (2013) Gender differences in access to extension services and agricultural productivity. Journal of Agricultural Education and Extension 19: 437-468.

23. Dufera GL, Wollega A (2018) The Ethiopian Agricultural Extension System and Its Role as a Development Actor: Cases from Southwestern Ethiopia.
24. Beneberu A Wondimagegnhu, Admassu T Huluka, Sarah M Nischalke | (2019) Determinants of farm livelihoods of smallholder farmers in Yayu biosphere reserve, SW Ethiopia: a gender disaggregated analysis, Cogent Economics \& Finance 7(1): 1645583.

25. Alemayehu Gemechu (2017) The Practices of Farmers Training Centers' In Enhancing Rural Livelihoods: The Case of Dawo Woreda, Oromia Regional State. A Thesis Submitted to the Department of Curriculum and Instruction, in Partial Fulfillment of the Requirements for the Degree of Master of Arts in Adult Education and Community Development.

26. AGRA (2018) Africa Agriculture Status Report: Catalyzing Government Capacity to Drive Agricultural Transformation, Alliance for a Green Revolution in Africa, Nairobi, Kenya. 